\title{
Application of cost accounting systems in an enterprise
}

Ph. D. Paweł Kużdowicz University of Zielona Góra Faculty of Economics and Management

Ph. D. Dorota Kużdowicz University of Zielona Góra Faculty of Economics and Management

\section{Introduction}

In economic practice, various cost accounting systems are applied, which differ by time horizon and accounting scope. Because of the different information needs of various groups of stakeholders (e.g. directors, owners, subsidiaries), there are often several systems in place. This may lead to divergence in results. This does not only concern situations where there is one system in financial accounting (e.g. actual cost accounting) and other systems in the managerial accounting (e.g. normal and planned cost accounting). The divergence caused by the simultaneous application of different cost accounting systems may lead to misinterpretations and incorrect business decisions being made. This raises the need to reduce data from various systems to the lowest 'common denominator', i.e. their recalculation to results determined in the base system. (Kużdowicz, Kużdowicz, Witkowski 2012).

This article presents connections between cost accounting characteristic for managerial accounting and financial accounting within the normal and actual cost accounting systems. The research problem is to find the 
answer to the question: is there a procedure for reconciling result data specified in normal and current cost accounting?

\section{Cost accounting systems}

In respect of time horizon, there is actual cost accounting, normal cost accounting and planned cost accounting. Actual cost accounting records and accounts for - ex post - the effectively incurred costs. Normal cost accounting is based e.g. on average actual values from past periods, and planned cost accounting on normative or postulated values relating to the future (Schmidt 2008; cf. Biernacki, Kowalak, 2010; por. Kotapski, Kowalak, Lew, 2008).

\subsection{Actual cost accounting}

Actual cost accounting is a traditional cost accounting method that is limited to business activity with respect to the consumption of production factors and origination of products or services (results). The effectively incurred costs are valued based on actually incurred (actual) prices. This information is used to determine the actual profit/loss in the profit and loss account and determine cost per cost-object as part of the final calculation. This does not, however, provide for effective cost control, since it does not include the reference values as a basis of all comparisons. This means that the application of actual cost accounting only partially helps in making business decisions determining future costs and results (products, services) (e.g. Hoitsch, Lingnau 2007; cf. Kasperowicz, 2009).

In economic practice, there is no such thing as "pure" actual cost accounting, since a portion of types of cost is embedded in planned values. For instance, write-downs on machinery are made according to pre-defined useful life, since the actual period is set only after disposal (sale or write-off) of a given asset. Moreover, some one-off or non-cyclical expenses such as insurance premiums, holiday pay or taxes on vehicles are accrued using mean values. Allocating such expenses to the period in which they originate would lead to unreasonable cost fluctuations in an enterprise. "Pure" actual cost accounting would call for repeated determination of calculation rates and cost object calculation at the end of each reporting period (Schmidt 2008; Kużdowicz, Kużdowicz, Witkowski 2012). 


\subsection{Normal cost accounting}

To simplify actual cost accounting and perform initial calculations, fictitious costs and results (products, services) values are set. They are based on average values of costs from previous periods, which are adjusted to the present or expected changes in future prices and quantities, and are determined in normal cost accounting. This approach eliminates the impact of periodical fluctuations and accidental changes in consumption quantities or prices. For instance, additional costs, originating as an effect of a seasonal low or introduction of new product series, cannot be allocated only to units manufactured over a given period, but should be divided into the anticipated annual quantity or over the entire product life cycle. Such an approach causes a steady development of cost calculation rates and calculation rates, which guarantees calculation continuity (Kużdowicz, Kużdowicz, Witkowski, 2012).

Calculation rates are used to determine labour cost costs and machine hours. Calculation rates called surcharge rates are used to determine the overhead cost surcharges in prime cost calculation of calculation objects. Rates determined in normal cost accounting, being normal rates, are also applied in allocations and calculations in actual cost accounting. This applies in particular to the initial actual calculation, where at the time of delivery - e.g. at the beginning of the reporting period - only normal rates can be applied. Actual rates will be known only at the end of the period. Calling the system the "actual cost accounting" appears to be justified as long as the quantities of consumption are based mostly on actual values (Schmidt 2008).

\section{Record and cost allocation}

\subsection{Stages of cost accounting}

Cost accounting as an information processing system includes a series of ordered and logically connected activities. The key purpose of these activities consists in translating data on the use of resources involved in the company's operations into information which reflects the costs of specified reference objects (Nowak, Wierzbiński, 2010).

The reference objects include cost types, centers and drivers. The record and cost allocation covers the cost by-type accounting and cost centre and object accounting. Object accounting is divided into cost object accounting related 
to unit calculation objects and income object accounting, related to time. Cost accounting and allocation takes place in financial and managerial accounting, however primary costs (consumption or external resources) are accounted for simultaneously in financial and managerial accounting, whereas secondary costs are accounted for only in managerial accounting. Direct costs are accounted for directly to cost accounting objects, and overhead (indirect) costs - sequentially, i.e. first in cost types and cost centres and then in cost object and/or income object accounting. Figure 1 illustrates the stages of cost accounting.

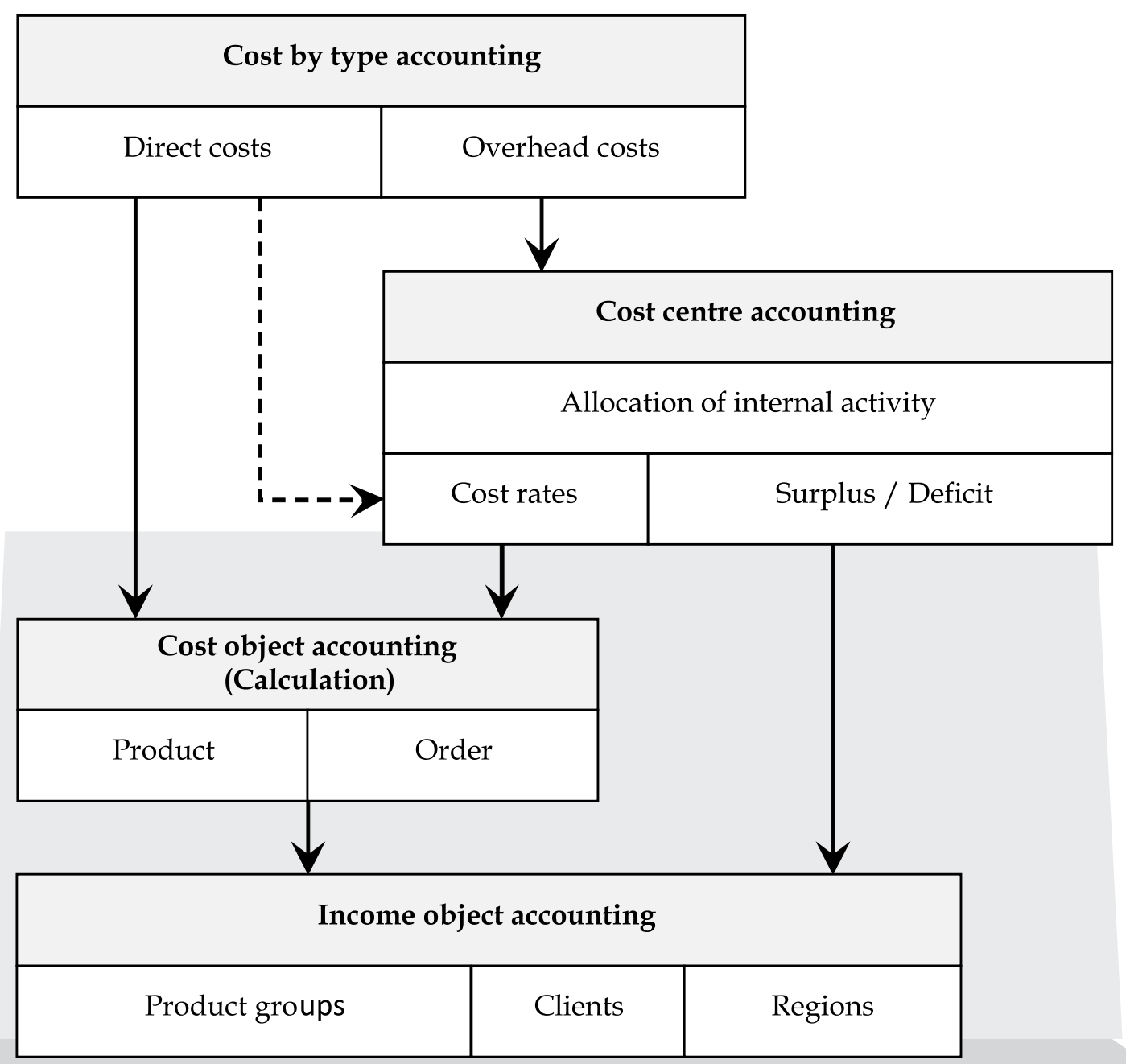

Fig. 1. Stages of cost accounting

Source: Schmidt 2008, p. 40 
By nature, direct costs may be directly "transferred" to the cost object accounting. Sometimes, they are allocated to cost centres in a purely informative manner or as a basis for overhead costs accounting. Overhead costs are always allocated in relation to cost centres. This is where they are accounted for and allocated as part of intercompany exchange of performance. Then, with reference to each cost centre, the cost rates are determined (i.e. allocation rates and surcharge rates). The rates are used to allocate overhead costs to one unit of a given cost object, for example product or order (calculation). Besides that, overall overhead costs of the period are recognized in the income objects and compared with the products/services of this period. If, in a given period, too many or too few overhead costs were allocated, the resultant cost surplus or deficit is recognized in income object accounting. Income object accounting, besides the result achieved in a given reporting period, also gives information about its sources, provided that a proper division into objects was made (cf. Schmidt 2008). Income objects may be, for example, groups of articles, clients, regions, etc.

Cost by-type accounting and cost centre accounting normally takes place as part of the so-called cost accounting sheet - recognition that shows in the horizontal axis as costs by cost centre, and in the vertical axis as cost types. The organization and "closed" connection to cost and income object accounting takes place through cost rates, and through accounting of cost surplus or deficit.

\subsection{Allocation of cost centre surplus and deficit}

Actual surcharge rates can increase or decrease every month, since both overhead costs and the reference values fluctuate over time. This is caused by e.g. irregularity of the production factors consumption or fluctuations of the surcharges bases, resulting from, for instance, a different number of working days in a month. With a view to ensuring cost recording continuity, cost calculation and accounting indeed take place based on actual values of the reference values - however not at actual but normal cost rates determined over a longer period. Actual monthly cost rates usually oscillate around a normal cost rate (por. fig. 2).

When accounting cost using a normal cost rate, differences between the actually incurred overhead cost and the accounted overhead costs (= normal overhead costs) of cost centres may emerge, which are determined as cost centre surplus (+) or deficit (-). Surpluses occur when normal overhead costs are higher than actual overhead costs, i.e. when the normal surcharge rate is higher than the actual surcharge rate. Otherwise, deficit occurs. 


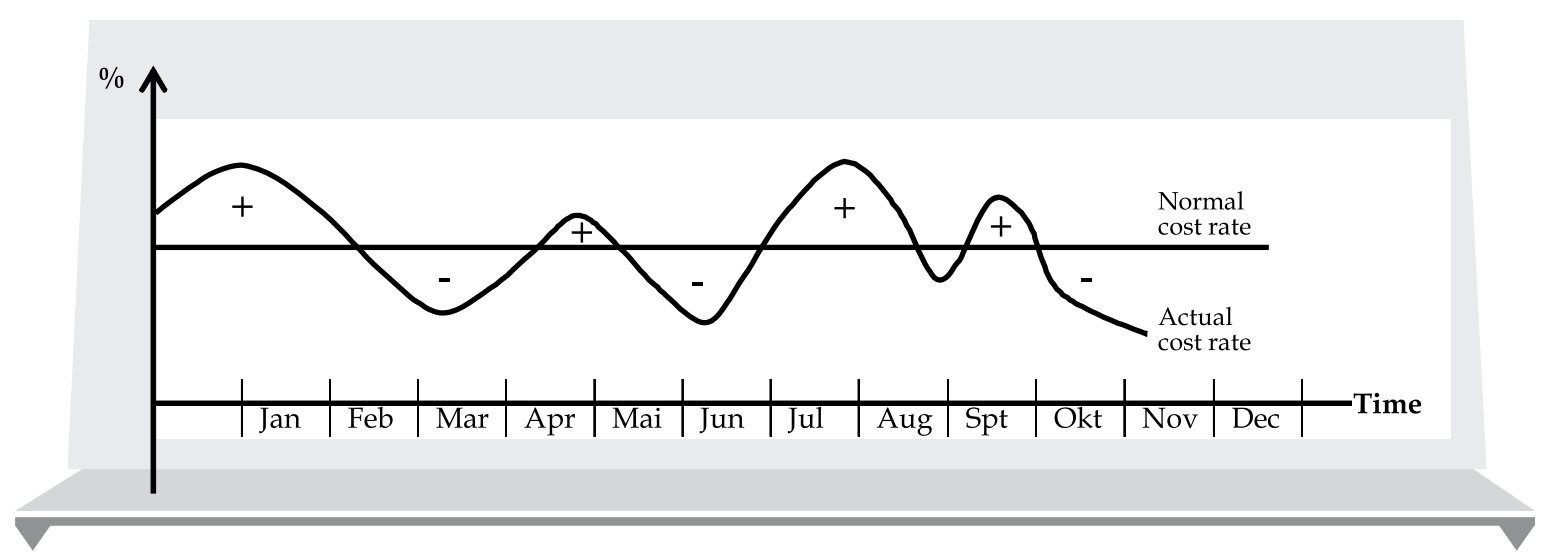

Fig. 2. Oscillation of the cost rates

Source: own study

Cost accounting is then a coherent system even if each element is incompatible time-wise (Kużdowicz, Kużdowicz, Witkowski, 2012). In practice, this coherence is ensured by ERP (Enterprise Resource Planning) systems, within the so called data flow functionality (Kużdowicz, Relich., Kużdowicz, 2012). The example of the application of the considered concept with special emphasis on relations between individual areas of financial and managerial accounting is discussed later in the article.

\section{Illustrative examples}

The example illustrates the application of the concept in the cost accounting system covering cost types, cost centres, cost objects and income objects. The $\mathrm{SME}$ covered is a medium-sized job lot manufacturer.

\subsection{Cost centre accounting}

The following auxiliary cost centres were differentiated: Maintenance and Quality Management and main cost centres: Purchasing, Manufacturing, Assembly and Sales, according to the typical functional areas of management (cf. Kes, Dynowska, 2011). Calculation objects are products (being cost objects and income objects) $\boldsymbol{A}, \boldsymbol{B}$ and $\boldsymbol{C}$ representing a range of assortment groups.

Table 1 illustrates the cost centre analysis sheet containing overhead costs, surcharge rates, normal costs allocation (to cost objects) and surplus and deficit by cost centre. Overhead costs have been divided into primary and secondary. Cost 
allocation means: primary cost allocation (in auxiliary and main cost centres); secondary cost allocation (ultimately only in main cost centres); allocation of normal costs to objects and determination of surplus or deficit for individual cost centres.

Table 1. Cost centre analysis sheet

\begin{tabular}{|c|c|c|c|c|c|c|c|}
\hline (in $\mathrm{k}$ PLN) & $\begin{array}{l}\text { Mainte- } \\
\text { nance }\end{array}$ & $Q M$ & $\begin{array}{c}\text { Pur- } \\
\text { chasing }\end{array}$ & $\begin{array}{l}\text { Pro- } \\
\text { cessing }\end{array}$ & Assembly & Sales & Total \\
\hline \multicolumn{8}{|l|}{ Primary costs } \\
\hline Depreciation & 10,0 & 20,0 & 10,0 & 25,0 & 15,0 & 20,0 & 100,0 \\
\hline Payroll & 20,0 & 15,0 & 20,0 & 50,0 & 90,0 & 60,0 & 255,0 \\
\hline Energy & 8,0 & 20,0 & 5,0 & 22,0 & 35,0 & 8,0 & 98,0 \\
\hline Other & 2,0 & 5,0 & 15,0 & 3,0 & 10,0 & 2,0 & 37,0 \\
\hline $\begin{array}{l}\text { Total primary costs } \\
\text { (actual) }\end{array}$ & 40,0 & 60,0 & 50,0 & 100,0 & 150,0 & 90,0 & 490,0 \\
\hline \multicolumn{8}{|l|}{ Secondary costs } \\
\hline $\begin{array}{l}\text { Maintenance cost } \\
\text { division }\end{array}$ & $-48,0$ & 2,4 & 7,2 & 16,8 & 9,6 & 12,0 & - \\
\hline QM cost division & & $-49,6$ & 0,0 & 17,6 & 32,0 & 0,0 & - \\
\hline $\begin{array}{l}\text { Costs after division } \\
\text { (actual) }\end{array}$ & $-8,0$ & 12,8 & 57,2 & 134,4 & 191,6 & 102,0 & 490,0 \\
\hline
\end{tabular}

\begin{tabular}{l|l|l|l|l|l|l}
\hline $\begin{array}{l}\text { Surcharge rates } \\
\text { (normal) }\end{array}$ & $11 \%$ & $120 \%$ & $300 \%$ & $12 \%$ & \\
\hline
\end{tabular}

\begin{tabular}{l|ll|l|l|l|l|l}
\hline $\begin{array}{l}\text { Cost allocation to objects } \\
\text { (normal) }\end{array}$ & & $-87,3$ & $-165,5$ & $-142,0$ & $-146,3$ & $-541,2$ \\
\hline Cost Surplus/Deficit & $\mathbf{- 8 , 0}$ & $\mathbf{1 2 , 8}$ & $\mathbf{- 3 0 , 1}$ & $\mathbf{- 3 1 , 1}$ & $\mathbf{4 9 , 6}$ & $\mathbf{- 4 4 , 3}$ & $\mathbf{- 5 1 , 2}$ \\
\hline
\end{tabular}

Source: own study

Overhead costs totalling PLN 490.0k after secondary cost allocation, are divided into cost centres in the following amounts: PLN -8,0k;12,8k;57,2k;134,4k; 191,6ki $102,0 k$. The costs of the main cost centres were allocated to cost objects based on normal surcharge rates for cost centres in the following amounts, respectively: PLN -87.3k; -165.5k; -142.0k and -146.3k (cf. table 2), which caused a deficit for cost 
centres in the following amounts, respectively: PLN -8,0k; 12,8k;-30,1k; -31,1k; 49,6k $i-44,3 k$. This shows deficit in Maintenance, Purchasing, Processing and Sales cost centres and surplus in $Q M$ and Assembly cost centre. Total deficit is PLN $-51.2 k$ and is to bring normal values of profit/loss on sales determined based on normal costs to the actual values (cf. table 3).

\subsection{Cost object accounting}

Cost object accounting being the calculation of prime costs is illustrated by table 2 . The table shows cost item analysis as a breakdown of costs that make up prime cost of calculation objects. Direct costs are made up of raw materials, labour cost costs. Overhead costs are allocated through surcharge rates. As reference values determining overhead cost surcharges, the following were assumed for cost centres: raw materials, labour cost and cost of products sold. For instance, the overhead costs surcharge of purchasing for product $A$ is PLN $42.4 k(=11 \%$ $\mathrm{x} 56.0) \mathrm{k}$. The cost added to cost object (product $A$ ) and reduced the cost centre (Purchasing) - at normal value, which is reflected in cost centre analysis sheet under 'Cost allocation to objects (normal)'.

Table 2. Cost item analysis sheet

\begin{tabular}{|c|c|c|c|c|c|c|}
\hline & (in k PLN) & $\begin{array}{c}\text { Sur- } \\
\text { charge }\end{array}$ & $\begin{array}{c}\text { Product } \\
A\end{array}$ & $\begin{array}{c}\text { Product } \\
B\end{array}$ & $\begin{array}{c}\text { Product } \\
\text { C }\end{array}$ & Total \\
\hline & Raw materials & & 385,0 & 280,0 & 129,0 & 794,0 \\
\hline+ & Overhead costs of Purchasing & $11 \%$ & 42,4 & 30,8 & 14,2 & 87,3 \\
\hline+ & Labour cost of Processing & & 83,6 & 31,0 & 23,3 & 137,9 \\
\hline+ & Overhead costs of Processing & $120 \%$ & 100,3 & 37,2 & 27,9 & 165,5 \\
\hline+ & Labour cost of Assembly & & 27,4 & 18,1 & 1,9 & 47,3 \\
\hline+ & Overhead costs of Assembly & $300 \%$ & 82,1 & 54,3 & 5,7 & 142,0 \\
\hline$=$ & Costs of goods & & 720,8 & 451,4 & 202,0 & $1.374,1$ \\
\hline+ & Product stock decrease & & - & - & - & - \\
\hline- & Product stock increase & & 150,0 & - & - & 150,0 \\
\hline- & Activated internal activities & & - & - & 4,7 & 4,7 \\
\hline$=$ & Cost of products sold & & 570,8 & 451,4 & 197,3 & $1.219,4$ \\
\hline+ & Overhead selling costs & $12 \%$ & 68,5 & 54,2 & 23,7 & 146,3 \\
\hline$=$ & Prime costs (normal) & & 639,2 & 505,6 & 220,9 & $1.365,8$ \\
\hline
\end{tabular}


Cost item analysis in addition illustrates changes in value of product stock and activated own work; it was assumed that the value of stock of product $A$ increased by PLN 150.0k (for make-to-stock, MTS), and of product C by PLN $4.7 k$ (for own work capitalized). The inclusion of movements in stock enabled to separate the cost of products and cost of products sold. The latter is a base for determining the surcharge of overhead selling cost, which for product $A$ is PLN $68.5 k(=12 \% \times 570.8) k$.

\subsection{Income object accounting}

Income object accounting means the allocation of direct costs and overhead costs to calculation objects. Direct costs are valued at actual values and overhead costs at normal values (as a quotient of normal surcharge rates and reference values). The assumption of normal values to overhead cost accounting means determination of prime costs based on normal costs. Bringing the results to the actual (actual) values requires inclusion of surplus and deficit of overhead costs determined in cost centre accounting.

Table 3 is an example of determination of profit/loss on sales based on normal costs brought to profit/loss on sales, based on actual values. In the contemplated example, this caused an increase in profit on sales from PLN 206,7k to 257,9k. Income object analysis patterned after a profit and loss account in the multi-step format in a simplified version was used here.

Table 3. Profit and loss account (multi-step format)

\begin{tabular}{|c|c|c|c|c|c|}
\hline & (in k PLN) & $\begin{array}{c}\text { Product } \\
A\end{array}$ & $\begin{array}{c}\text { Product } \\
\text { B }\end{array}$ & $\begin{array}{l}\text { Product } \\
\text { C }\end{array}$ & Total \\
\hline & Sales revenue & 841,5 & 495,0 & 236,0 & $1.572,5$ \\
\hline- & Prime costs (normal) & 639,2 & 505,6 & 220,9 & $1.365,8$ \\
\hline$=$ & Profit/loss on sales (normal) & 202,3 & $-10,6$ & 15,1 & 206,7 \\
\hline+ & Surplus of overhead costs & & & & 51,2 \\
\hline- & Deficit of overhead costs & & & & - \\
\hline$=$ & Profit/loss on sales (actual) & & & & 257,9 \\
\hline
\end{tabular}

The results were verified by preparing the profit and loss account in a singlestep format in a simplified version (cf. table 4). Unlike cost centre analysis sheets 
and cost item analysis sheets prepared in managerial accounting, the profit and loss account in a single-step format is prepared only in financial accounting.

Table 4. Profit and loss account (single-step format)

\begin{tabular}{|c|c|c|c|}
\hline & & (in k PLN) & Total \\
\hline & Sales revenue & & $1.572,5$ \\
\hline- & Product stock decrease & & - \\
\hline+ & Product stock increase & & 150,0 \\
\hline+ & Activated internal activities & & 4,7 \\
\hline$=$ & Sales and equivalent & & $1.727,2$ \\
\hline- & Overhead costs (actual) & & 490,0 \\
\hline - & Raw materials (actual) & & 794,0 \\
\hline- & Labour cost (actual) & & 185,3 \\
\hline$=$ & Profit/loss on sales (actual) & & 257,9 \\
\hline
\end{tabular}

The verification is positive; bringing normal values to the actual ones, which enables reconciliation of data in financial and managerial accounting. Multiplestep and single-step format cost accounting lead to - as shown by the example the same profit/loss on sales as long as movements in stock of products and own work capitalized are valued the same. Calculated manufacturing costs were valued based on normal costs. This means that for applying cost accounting in the single-step format, calculation is necessary. Multiple-step format cost accounting assumes calculation and means no necessity to show movements in stock of finished products and work in progress, and activated internal activities.

\section{Conclusions}

The article discusses the application of different cost accounting systems in an enterprise. Special attention has been paid to the connection between financial and managerial accounting. An example illustrating the implementation of normal and actual cost accounting systems in a manufacturing enterprise was given. It was demonstrated that despite applying normal cost rates for calculation, the correction of cost accounting using cost centre surplus/deficit 
always guarantees complete integration between the cost centre accounting and cost object accounting and income object accounting, and thereby determination of the actual result. The analysis has shown the usefulness of the approach in the context of reconciliation of results in financial accounting and cost accounting. Future research will be dedicated to identification of connections and flows between the cost centre accounting, cost object accounting and income object accounting. These are related, in particular, to the identification of deviations between normal and actual direct cost values.

\section{Summary}

Application of cost accounting systems in an enterprise

The Article discusses the issue of allocation of costs in the normal and actual cost accounting systems. A procedure of dump (conversion) of the normal into actual costs using data flows has been presented. The Article presents an example of applying the designed procedure illustrating the links between cost centre, cost objects and income objects accounting.

Keywords: system, normal and actual cost, data flows

\section{Streszczenie}

Zastosowanie systemów rachunku kosztów w przedsiębiorstwie Artykuł podejmuje problematykę rozliczenia (alokacji) kosztów w systemach ramach rachunku kosztów normalnych oraz bieżących. Zaprezentowano procedurę sprowadzania kosztów normalnych do kosztów bieżących z wykorzystaniem potoków danych. W artykule przedstawiono przykład zastosowania opracowanej procedury ilustrującej powiązania pomiędzy rachunkami centrów

Słowa kosztów, nośników kosztów oraz nośników wyników.

kluczowe: $\quad$ system, koszty normalne i bieżace, potoki danych

\section{References}

1. Biernacki M., Kowalak R. (2010), Rachunek kosztów logistyki w zarządzaniu przedsiębiorstwem, Wydawnictwo UE, chapter 2; Wrocław, pp. 29-61.

2. Haberstock, L. (2008), Kostenrechnung I - Einführung mit Fragen, Aufgaben und Lösungen, 13. Aufl., Schmidt, Erich Verlag, Hamburg.

3. Hoitsch, H. J., Lingnau (2007), V., Kosten- und Erlösrechnung. Eine controllingorientierte Einführung, 6. Aufl. Springer Verlag, Berlin. 
4. Kes Z., Dynowska J. (2011), Management functions vs. budgeting process. Performance Measurement and Management, red. B. Nita, Wrocław, No 123, pp. 39-48.

5. Kasperowicz A. (2009), Rachunek kosztów cyklu życia produktu w zarządzaniu przedsiębiorstwem, red. R. Kowalak, Wydawnictwo UE, Wrocław, rozdziały: 1.1-1.3 (s. 9-29), 10 (s. 208-227).

6. Kużdowicz P., Relich M., Kużdowicz D. (2012), Cross-company data flows with ERP system, Knowledge for Market Use 2012, Palacký University, Olomouc (Czechy), pp. 264-269.

7. Kużdowicz D., Kużdowicz P., Witkowski K. (2012), The application of normal and actual cost accounting in production companies, CO-MAT-TECH 2012: Global Crisis - Opportunities and Threats, 20th International Scientific Conference, AlumniPress, Trnava (Słowacja) [in print].

8. Nowak E., Wierzbiński M. (2010) Rachunek kosztów. Modele i zastosowania, PWE, Warszawa.

9. Kotapski, R., Kowalak R., Lew G. (2008), Rachunkowość zarządcza. Kompendium wiedzy, Wyd. Marina, Wrocław.

10. Schmidt, A., Kostenrechnung. Grundlagen der Vollkosten-, Deckungsbeitragsund Plankostenrechnung sowie des Kostenmanagements (2008), W. Kohlhammer Druckerei GmbH + Co. KG, Stuttgart. 